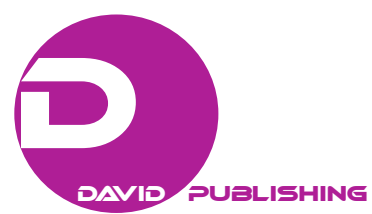

\title{
Toward the Economic Transformation of Africa*
}

\author{
Joseph Atta-Mensah \\ United Nations Economic Commission for Africa, Addis Ababa, Ethiopia
}

\begin{abstract}
Despite the severity of the global financial and economic crisis of 2007, Africa did not deep into a recession but rather saw its economies significantly slowdown. A question one may ask is how did Africa withstand the 2007 crisis. Although no definitive answer can be offered, one could suggest that the positive performance of Africa is due to the solid policies run by many African countries prior to the crisis. Experiences from other parts of the world indicate that if African countries continue their current economic performance then the rapid growth recorded prior to the financial crisis would result in substantial structural changes within the economies of many countries. The goal of many African countries, as enshrined in their development plans or strategies, is to reach middle-income-country status by the next decade. However, moving from low- to middle-income status would not only require an increase in per capita income but also structural transformation of the economies as an important part of development. The success of Asian and Latin American countries to embark on structural transformation of their economies to significantly uplift living standards of the poor raises several important questions for Africa. Firstly, can Africa draw lessons from these countries? Secondly, what are the roles private and public sectors as well as agriculture sector should play in initializing and sustaining a transformation? Thirdly, what is the impact of initial policies during the early stages of transformation on a country's long-term development path? The purpose of this paper is an attempt to answer the questions raised as well as offer policy prescriptions. Going forward it is within the grasp of Africa to transform itself into a middle-income continent within a generation. This will require a development agenda whose implementation is inclusive and it is aimed at uplifting majority of the citizenry from poverty as well as growing the middle class. Africa may consider using deeper forms of regional integration to boost intra-African trade as well as find innovative financing mechanisms support regional infrastructure. In concluding, it is very important for all Africans to note that Africa has to be developed by Africans. "Hand outs" glorified as aid/grants, alone will not change the lives of the many poor citizens of the continent. Ultimately, Africans are totally responsible for the development of the continent and therefore should shoulder the burden of financing its development, no matter how long it takes and how painful it may be.
\end{abstract}

Keywords: economic transformation, sustainable economic growth, technology, productivity and regional integration

\section{Introduction}

Despite the severity of the global financial and economic crisis of 2007, Africa did not deep into a

\footnotetext{
* Acknowledgements: The author thanks his colleagues at the UN for their valuable inputs. All opinions and errors are his and should not be attributed to the UN.

Joseph Atta-Mensah, Ph.D., principal policy adviser, Capacity Development Division, United Nations Economic Commission for Africa, Addis Ababa, Ethiopia.

Correspondence concerning this article should be addressed to Joseph Atta-Mensah, Capacity Development Division, United Nations Economic Commission for Africa, P. O. Box 3001, Addis Ababa, Ethiopia. E-mail: jattamensah@uneca.org.
} 
recession but rather saw its economies significantly slowdown. The channels, through which the crisis affected Africa, included among others, plummeting trade, the drying up of the flows of financial capital and remittances as well as treats of bank runs and weak financial intermediation. These negative influences caused Africa to register an average growth of $2 \%$ in 2007 , significantly down from about 5\%-7\% beforehand. Although there are currently turbulent head-winds coming out of the euro zone, the 2007 financial storm is behind and Africa's economy is roaring back, forecasted to grow between 5\%-7\% from 2013 to 2015. It is worth noting that that six (Ethiopia, Mozambique, Tanzania, Congo, Ghana, and Zambia) of the world's 10 fastest-growing economies are in Africa, recording at least $7 \%$ growth rate. The optimism beaming around the globe has led some commentators to predict that the average African economy will outpace its Asian counterpart in next five years. According to the respected Economist magazine, Africa which it dubbed a decade ago as a hopeless continent is currently bullish about the economic prospects of the continent, calling it the hopeful continent.

A question one may ask is how did Africa withstand the 2007 crisis. Although no definitive answer can be offered, one could suggest that the positive performance of Africa is due to the solid policies run by many African countries prior to the crisis. These policies, which inoculated the African economies against the severe ramification of the crisis included: low-inflationary monetary stance, prudent fiscal management (strengthened budget positions, reduced debt burdens, and reformed tax structure), and reasonable foreign currency reserve cushion. Improved fiscal position allowed countries to use the budget to counteract the crisis, rather than making it worse. Fiscal policy was therefore expectedly countercyclical in many African countries at the time of the crisis. It should be said that the fiscal cushion helped a great deal to protect the poor and vulnerable as social spending was not cut during the crisis.

Despite the current robust economic performance, Africa should not rest on its laurels as it remains vulnerable to shocks from different sources. These shocks could potentially come from volatility in commodity prices, natural disasters, climate change, wars, and conflicts as well as weakened flow of remittances, aid, and financial flows. The challenge for Africa is to continue to pursue an agenda of strong inclusive-growth at the same time reinforcing its resilience to shocks. This requires that Africa stays on course on its pursuant of sound macroeconomic policies. Hence, policy buffers must remain in place to allow for future countercyclical responses including prudent fiscal policy and the use of reserves. Social safety nets need to be strengthened as well. Social and income inequalities must also be aggressively addressed so as not to heighten tensions within the population in times of economic downturn and make shocks more destabilizing.

Experiences from other parts of the world indicate that if African countries continue their current economic performance, then the rapid growth recorded prior to the financial crisis would result in substantial structural changes within the economies of many countries. The goal of many African countries, as enshrined in their development plans or strategies, is to reach middle-income-country status by the next decade. However, moving from low- to middle-income status would not only require an increase in per capita income but also structural transformation of the economies as an important part of development.

A key challenge facing many African policymakers is how to maintain the pace of rapid growth while embarking on structural transformation. One can recall that the industrial planning strategy embarked by post-independent African countries in the 1960s and 1970s was a failure as it led to economic mismanagement and poor economic growth. Furthermore, the adoption by African countries in 1980s and 1990s of the Washington-Consensus-promoted policies of the laissez-faire market oriented strategies successfully yielded macroeconomic stability but failed to produce structural transformation and sustained growth. 
The success of Asian and Latin American countries to embark on structural transformation of their economies to significantly uplift living standards of the poor raises several important questions for Africa. Firstly, can Africa draw lessons from these countries? Secondly, what are the roles private and public sectors as well as agriculture sector should play in initializing and sustaining a transformation? Thirdly, what is the impact of initial policies during the early stages of transformation on a country's long-term development path? The purpose of this paper is an attempt to answer the questions raised. However, to answer these questions, there is a need for a better understanding of what constitutes structural economic transformation.

\section{Meaning of Economic Transformation}

The process of economic development is characterized by a period of rapid per capita growth combined with structural change. Syrquin (1988) defined economic transformation as the interrelated processes of structural change that accompany economic development. In other words, through the implementation of interventionist-policies, economic transformation can be attributed to the process in which a poor rural-based country becomes a middle-income country with a rising share of industry and services in gross domestic product (GDP) and employment. The transformation is generally characterised by the following patterns. ${ }^{1}$ First, during the transformation period, there are significant changes to economic structures. This is because industrialization ignites accelerated increases in the share of manufacturing in the economy and a consequent decline of the share of agriculture (Kuznets, 1973; Chenery \& Taylor, 1968). Second, the share of the total labour force employed in the agricultural sector falls, while that in other economic sectors rises. Third, agricultural productivity rises as a result of the use of modern agricultural technology and better seedlings. Fourth, the main driver of the country's economy shifts from rural areas to cities, and therefore degree of urbanization significantly increases. What these patterns mean is that economic transformation leads to the rise in the overall productivity and income per capita of the country as well as the rapid creation of new and higher-paid jobs. Furthermore, with the transformation, the country moves away from the production of primary products and into value-added products. Consequently, the economy becomes integrated in the global supply chains and as a result of its trade with the rest of the world, there is continuous learning by doing and up-grading of new technologies and skills sets as well as the expansion manufacturing capacities.

It is important to note that economic transformation may not lead to shared growth. In the short term, the transformation process could lead to uneven growth and rising income inequality. Kuznets (1955) was the first to suggest that income inequality might follow an inverse $U$ shaped relationship during the transformation process. The Kuznets curve predicts that initial stages of the industrialization process lead to an increase in income inequality. However, as the process continues, there is a significant decline in inequality as wages rise with higher labour productivity.

As economic transformation leads to modernization of a country's economy, society and institutions are also affected, because human life, values, norms, beliefs, and customs are also transformed from a traditional to a modern society. Moreover, shifts in production structures during transformation lead to changes in incentive structures, educational requirements, and the relative positions of different groups in society. Kuznets (1955) further argued that urbanization results in shifts in family formation, gender relations, and personal status. The transformation also changes transport and communication services, as production and distribution centres are

\footnotetext{
${ }^{1}$ It is important to note that these transformation patterns which are observed in new industrializing economies, such as those in Asia and Latin America, are very similar to those observed in European countries during the 19th and early 20th centuries.
} 
opened up connected to markets. The legal system has a vital role to play, as new laws are needed to preserve and uphold institutional innovations and property rights.

\section{Sources of Economic Transformation}

There is no clear agreement on what constitutes the sources of economic transformation. However, there are several sources of transformation, most of which are interrelated and very difficult to separate out (Breisinger \& Diao, 2008). Based on their extensive review, they grouped the sources of transformation into five: (i) technology-led productivity growth; (ii) rapid capital accumulation; (iii) the role of linkages; (iv) the roles of market, institutions, and governments in transformation; and (v) infrastructure development.

Technology-led productivity growth. Kuznets (1955) suggested that a country undergoing transformation from traditional to modern economy begins with the adoption of technology and innovations so as to rapidly boost productivity growth. Entrepreneurship and human capital plays an important role in this process as well. Such an environment supports the entrepreneurial spirit of the private sector to drive the development agenda (Schumpeter, 1947). To explain how technology led productivity growth leads to economic transformation, people should imagine a traditional economy made up of the agriculture sector (with an abundant labour force and uses primitive technology) and an industrial sector. Under this arrangement, the marginal product of labour in the agricultural sector is negligible, zero, or even negative. In the process of the modernization of the economy, with adoption of modern technology, one would observe production of added-value manufactures grows in the economy through the movement of labour from the agricultural sector to the industrial sector. With the growth in productivity, the economy will eventually converge to equalization in the marginal productivity of labour in the two sectors and higher economic growth.

It should be noted that rapid increase in productivity in the agricultural sector contributes to rapid economic growth in an economy-wide transformation. Before the transformation of an economy, author observes low marginal productivity in agriculture sector, because the factors employed in agriculture sector are primitive. However, the adoption of modern technologies during the transformation can make agriculture an important driver of rapid economic growth in addition to the significant contribution from a modernized industrial sector. Evidence in the literature suggests that the rapid agricultural growth in many Asian and Latin American countries in the 1960s and 1970s was driven by the adoption of new farming technologies, including the use of irrigation, high-yield crop varieties, and modern inputs such as fertilizer (Heath, 1992).

Rapid capital accumulation. During the transformation process, capital accumulation follows technology-led productivity growth. This is because most technologies are part of modern capital goods. The accumulation of capital and the subsequent increase in the savings rate is what supports capital investments in transformed countries. Capital investments in industry contribute significantly to rapid growth during the transformation process in low-income countries. Krueger (1988) noted that during the reconstruction of post-World War II, Europe investments in infrastructure and industry were an important component of rapid economic recovery and growth. It has to be noted that capital accumulation plays a very important role in rapid growth, implying that the share of investment in GDP increases significantly during the transformation process as they are used to finance the industrialization. It has to be pointed out that during the transformation, the revenue (export revenue) from the agricultural sector initially acts as surplus for the financing of capital formation necessary for industrial growth. 
The role of linkages. As noted above, productivity growth and capital accumulation are vital for economic transformation. In addition, the two sources of transformation also further enhance economic inter-linkages during the transformation process. Together they create the backward and forward linkages created by capital investments in the industrial sector. Furthermore, they promote interactions between agricultural and non-agricultural sectors as during the transformation agriculture not only acts as a source of surplus to support industrialization, but as a dynamic source of growth, employment, and more equal income distribution. The process of transforming traditional agriculture into a modern sector also enhances both consumption and production linkages between agriculture and non-agriculture and between rural and urban areas. These backward linkages occur, because of the increased demand of agriculture for modern inputs, such as fertilizer, improved seedlings and irrigation (produced by the manufacturing sector), marketing, trade, and banking (provided by service sectors). Consumption linkages, which are especially strong in low-income countries, lead to higher growth multipliers and poverty reduction effects. Furthermore, agricultural productivity growth allows higher agricultural output at lower costs and therefore provides cheap raw materials for various industries (e.g. food processing). This in turn opens up opportunities for the development and diversification of food manufacturing and marketing activities.

The roles of market, institutions, and governments. Institutions and markets are vital for the transformation to be successful. The quality of institutions and markets does influence the incentives to develop and use new technologies and innovations during the period of transformation. Rodrik (2004) indicated that institutional reforms are endogenous to the transformation process and not crucial at the beginning of the process. For the transformation to be led by the adoption of modern technology, the markets where the modern technological inputs are obtained have to be well functioning. It is therefore imperative that financing mechanisms, more functional and developed marketing systems, and supply chains built around smallholder farmers are in place to accompany the transformation sector as well as complementary investments in all links of the supply chain. Development of market institutions and investments in infrastructure and information systems contribute to reducing transportation and transaction costs and supporting farmers to use modern methods of production. Furthermore, the use of modern inputs and growing agricultural production can significantly deepen the market and increase profitability of small farmers in the process of transformation, further increasing their incentive to adopt modern technologies.

Given the existence of both market failures and government failures, there is a need for policymakers to have an understanding of the interaction between the public and private sectors and the role of institutions in transformation. Rodrik (2004) pointed out that the interaction is generally country-specific and the successful transformation of institutions and markets requires experimentation, a willingness to depart from orthodoxy, and attention to local conditions. However, in current times, the rapid demand for agricultural products has opened up new important opportunities for developing countries to find their paths to transformation through the joint efforts of private and public sectors.

Infrastructure development. Affordable infrastructure and services are very crucial in supporting the economic transformation of a low-income country. This is because infrastructure services have a strong growth-promoting effect through their impact on boosting productivity. Furthermore, investments in public infrastructure, in addition to its direct effects on the productivity of private inputs and the rate of return on private capital, spur growth through a variety of channels. A higher stock of public capital in infrastructure supports the transformation process, as it tends to raise the productivity of other inputs, such as labour and the 
stock of private capital, thereby reducing unit production costs in both the agricultural and industrial sectors. The increase in the productivity of private capital also raises the rate of private investment and consequently increases growth. In addition, enhancing labour productivity and lowering (unit) labour costs and "learning-by-doing" effects, which is a result of a high degree of complementarities, combine to magnify the growth effect of public infrastructure.

Infrastructure also accelerates economic growth through private capital formation. Investing in public infrastructure leads to increases in the marginal productivity of private inputs which in turn raises the rate of return on physical capital by the private sector. This can be explained with an example. The rate of return to establishing a factory in a country with well-developed power generation, transportation, and telecommunications will be higher than a country without such amenities. In the same vein, an integrated network of ports and roads can potentially contribute to massive increase in investment in major industries, spurring growth, and employment. Furthermore, investments in public capital in infrastructure affect private capital formation indirectly, through changes in output and relative prices. This raises the marginal productivity of all factor inputs (capital and labour), thereby lowering marginal production costs and increasing the level of private production. Through the standard accelerator effect, the scale affects output results in higher private investment and consequently higher production capacity over time thereby making growth effects more persistent.

\section{Chinese Experience}

China began its transformation process with agricultural reforms, particularly the land tenure system. It focused on changing the land arrangements for rural household so as to offer them enhanced incentives for increased production of food and consequently higher incomes. It started with a village-based experiment, whose success was quickly replicated around the country. The state also contributed its part by increasing its investments in infrastructure and technology in the rural regions which helped to accelerate food production. The resulting rural surpluses generated by small farms became the foundation for the whole system of national economic development. Consequently, the country witnessed the movement of capital and labour to towns and cities from an increasingly diversified and productive agricultural sector. These policies initiated China's current impressive growth path and formed the basis for its urbanization and export-oriented growth process.

China earlier on experimented with a special economic zone (SEZ). The SEZ, which was first, located in Shenzhen and replicated around the country, together with various industrial clusters and networks, is credited to be the basis of a supply chain-based model of industrial learning. The country supported its reform of the rural economy with policies that saw the liberalisation of the domestic market to encourage privatisation. Consequently, highly competitive enterprise-based economy was on the ascendancy supported with first class extensive regional and national transport linkages. China used international aid effectively for its transformation. It used aid and foreign direct investment to complement national resources and not as a major on-going financing stream. The Chinese authorities also used foreign aid and investment to advantage, using the two to acquire technical know-how and management skills which were critical for the modernisation of Chinese agriculture, industry, and infrastructure. Furthermore, bilateral and multilateral donors were brought in to provide considerable expertise, knowledge, and training in world-class analytical methods for public management and economic development. Even China's decision to join the WTO was made with the 
involvement of the population, by conducting nation-wide discussions on the benefits and challenges of the country engaging in the global economy.

The provision of affordable but durable infrastructure, science and technology, as well as higher education of the youth was at the heart of China's transformation. These policies were carried out by all levels of governments (state and provincial and city authorities). High-quality institutional infrastructures for higher education, including management training, were created at rapid pace around the country. The private sector also boomed around the country, benefiting from accelerated learning processes through engagements in international supply chains and joint ventures with foreign investors. In addition to engaging eminent international experts in their industries, scholarships were instituted for the youth to acquire graduate degrees abroad as well as mechanisms put in place to attract Chinese expatriates back home. All these measures contributed significantly to the transformation. Above all, deeper, close, and forward-looking interactions between policymakers and industry continue to be an essential part of the growth model of China.

Contrary to popular thinking, the Chinese government has cultivated and nurtured the private sector, playing a dominant role in the economy of the country. The private sector stands as the major source of employment, accounting for over $90 \%$ of the labour force. The contribution of the Chinese private sector also accounts for over $70 \%$ of its GDP. Furthermore, the management of state enterprises and the financial sector, which are dominated by state banks, is based on sound market and business principles and extensive external business linkages, including Africa, for example, the Industrial and Commercial Bank of China (ICBC) owns $20 \%$ of the Standard Bank in South Africa.

It is worth noting that China's successful transformation has been achieved at the cost of number serious economic, social, and environmental costs. The country faces structural economic imbalances, as some regions are well developed while some other regions have been left behind from the transformation. There is also a gulf between the rural and urban areas, as the challenges of land rights issues, internal migration stresses, natural resource degradation associated with intensive farming and social disparities. Income inequality remains and about 170 million Chinese are extremely poor, living on less $\$ 1$ a day.

\section{Guiding Principles of the Chinese Model}

One may ask what guided the Chinese to achieve so much in a generation. The fundamental principles that China followed during its transformation, among others are:

(1) responsible development-oriented state;

(2) self-reliance and ownership;

(3) performance-based public management and decentralisation;

(4) policy research capacities and innovation systems;

(5) feedback mechanisms for identifying and addressing challenges.

The guiding principles which China continues to follow are largely responsible for significantly reducing poverty, growing the middle class, and accelerating economic growth.

Responsible development-oriented state. Culminating from the open-policy of Deng Xiaoping, the leadership of China, since the 1970s, has made economic transformation its central focus. The state embarked on reforms and introduced policies that allowed for the building of consensus and participation across society in the transformation of the country. Evidence-based policies were initiated which ensured that performance was measured in terms of the growth of the economy and poverty reduction. Periodic review of performances was 
carried out so as to encourage learning and innovations as well as efficiency and effectiveness of government and private enterprises. The government also placed high priority on policymaking capacity by scaling-up investments in universities and research institutions, linking them to ministries as well as the decision and implementation processes. Furthermore, the government supported and encouraged the emergence of a well-educated professional middle class and used measured incentives to attract talented Chinese living outside the country to return home to work.

Self-reliance and ownership. China's transformation was also based on a strong principle of ownership and self-reliance. In other words, China controlled its own development path. This principle did not prevent the country from learning and adapting to knowledge from external partners, investors, and experts. As a result, China has developed its own medium and long-term development strategies, which are implemented with its Five-Year Plan instrument. To ensure their effectiveness, the use of external support, such as foreign investment and aid, was incorporated into development strategies. Periodic monitoring and evaluation of the strategies are constantly carried out and lessons learned are used to strengthen the strategies and associated implementation processes.

Performance-based public management and decentralisation. To ensure the success of the transformation, the Chinese government put in place a mechanism that ensured high quality public management teams for policy formulation and implementation at central and local levels. This meant reforming procedures for hiring civil servants and political officers, requiring the attainment of tertiary education. The government also replaced central planning systems with a market oriented planning system as well as decentralisation and delegation of decision-making processes. Competition between cities and towns in terms of development was encouraged so as to promote increased growth and poverty reduction. Furthermore, the taxation system was reformed at all levels of governments which in turn led to improved budgeting and increased revenues.

Policy research capacities and innovation systems. Based on evidence, the government frequently tested, assessed, and adjusted policies adopted to support the transformation. As a result, China has established an extensive set of institutional capacities in the hard and soft sciences, which carry out analysis of performance as well as find solutions to problems. In addition, higher education and research institutions have been rapidly expanded and linked to policy decision making and implementation. China also seeks world-expertise to complement local know-how in areas where it is weak and by this ensures that China is not left out from acquiring latest knowledge and technology.

Feedback mechanisms for identifying and addressing challenges. Despite its successes, the transformation process also produces socio-economic stresses and imbalances. Attempts to address the challenges have included a focus on the quality of growth as well as tackling income and regional disparities. The government has also put in place mechanisms that promote domestic consumption and reduce reliance on external demand. The government is also focused on repairing the environmental damage caused by the transformation, including farmland degradation, and managing urbanisation. With an aim of becoming a high-income country and playing an active part of the global governance system, China constantly reviews and adjusts its implementation processes. These reviews and adjustment are informed by feedback mechanisms and shocks to the global system.

\section{A Framework for Economic Transformation of Africa}

Prior to the financial and economic crisis of 2007/2008, Africa's economy was growing at an average rate 
of $6 \%$. Inflation was in single digit before the fuel and food price crisis in 2008 and the balance sheet of external reserves was deep in the black. These impressive economic indicators were achieved on the backs of sound macroeconomic policy reforms, favourable terms of trade, and debt relief. However, the crisis knocked off $4 \%$ off Africa's impressive average growth rate, registering about $2 \%$ in 2009 . Reasons for the slow growth in 2009 included weakness in global demand for commodities and the collapse of commodity prices. This caused Africa's export revenues to fall substantially by about $\$ 250$ billion in 2009 and consequently a number of African countries faced a deterioration of their external positions with widening current account deficits and declining international reserves. The current account balance declined from a surplus of $2.7 \%$ of GDP in 2008 to about deficit of $5 \%$ of GDP in 2009, a worsening by $8 \%$ of GDP in one year.

Africa has experimented with a number of economic models, which ranges from central planned economies, on the extreme left, markets-determined economies, on the extreme right, and everything in between. In addition, Africa has been forced to pursue a donor-driven agenda initiatives, such as the structural adjustment programmes, poverty-reduction strategies, millennium development goals (MDGs) to name a few. Despite all these well-intended initiatives, until the turn of the millennium, the continent's economic performance has been abysmal. To make progress and sustain the current healthy growth, Africa needs to understand where it got its policies wrong and determine a future path that will lead to sustain propriety, uplifting many Africans from poverty.

Despite the noble efforts by many African countries to follow the prescriptions of Washington Consensus of stabilization, liberalization, and privatization, there are arguments being waged by some commentators indicating that African countries are not performing as well as Brazil, Russia, India, Indonesia, China, and Korea (BRIICK) because of a number of reasons (Rodrick, 2007). One of the arguments is that African countries have not undertaken deeper reforms. This claim is not fair as Africa has undertaken far more Washington Consensus Style reforms than any region on the globe, resulting in stable inflation, more opened to international trade, and greater roles to markets in economic decisions. The weakness in the argument lies in the manner in which the current growth success is being attributed to the pursuit of sound economic reforms by African countries. This jobless-growth is mainly driven by oil, minerals, and other commodities.

A second reason ascribed to Africa's performance is what Rodrick (2007) described as "the check is in the mail" argument. The argument suggests that the "payoffs" from reforms are yet to be derived and therefore calls for patience. Rodrick (2007) demised this claim by arguing that growth follows immediately when the right policies are pursued and therefore there is no empirical evidence to indicate that the returns to reforms tend to be delayed a decade or more.

A third reason for blaming Africa for not performing as well as the BRIICK is because of external shocks, including the overall slowdown in industrial country growth. The BRIICK faced the same external environment and performed very well. Why has Africa not performed equally well?

The fourth one is that there is the argument which portends that the rate at which countries grow is substantially determined by three things: their ability to integrate with the global economy through trade and investment; their capacity to maintain sustainable government finances and sound money; and their ability to put in place an institutional environment in which contracts can be enforced and property rights can be established. The argument has been stretched further to say that Africa does not have the three things suggested. As much as the three conditions proposed are necessary, they are not sufficient. The BRIICK countries did not embrace the three conditions at the initial stages of their transformation. As indicated earlier, China undertook 
its reforms in its own way and on its own terms. China did not start its transformation by simply liberalizing and opening up its economy. It runs a dual track: a market track and a plan track. It had the town village enterprises (TVE), which were owned by the towns and villages and operated on market principles. Instead of liberalizing across the board, China pursued its trade liberalization through SEZ.

There is no doubt that for Africa to make progress with its transformation agenda, it has to, in the mediumto long-term, adopt to certain principles, including: (i) economic diversification; (ii) the maintenance of macroeconomic stability; (iii) reliance on market forces to signal prices; (iv) full integration into the world economy; and (v) protection of property rights and enforcement of contracts. These principles must be underpinned by a strong sense of African ownership, affordable high-quality infrastructure, strong social cohesion and political stability, strong economic and political governance, as well as prudential regulations of the market. However, in the short- to medium-term, African countries may wish to implement policies that will ensure that its industries are in a strong position to compete globally and there is enough social protection to handle the ill effects of complete implementation of market reforms.

The arguments raised in this paper and the experience of China and others suggest that Africa needs to embark on a similar trajectory of transformation, but with full ownership of the process and at its own pace. Africa has to have a clearly laid down strategy, which is practical and can be implemented. An interesting point to note is that many African countries are making tremendous efforts to transform their economies and are at income level similar to the levels Asia and Latin American countries were when they started their transformation agenda.

It should also be noted that the transformation process in Africa could be faster than elsewhere, given technological leapfrogging, learning from the experiences of the BRIICK as well as its integration in the global market place. The penetration of internet and mobile telephony, the affordability of computers, and the undersea fibre-optic cables currently in place suggest that the transformation can be faster, because the other emerging economies did not have them when they started their transformation agenda. Africa's interaction with the BRIICK has also enhanced the flow of ideas and knowledge which Africa can draw on for its transformation.

Going forward, what should Africa do to transform itself? Although one does have all the answers to Africa's developmental challenges and therefore the blue print for its transformation agenda, the suffering of a broad majority of the population as a result of deep-seated poverty calls to action for Africa to embark on a massive transformation agenda. Among others, African countries may consider the following as part of the agenda.

\section{Agricultural Modernization}

The first plank of a transformation agenda should be agricultural reforms and development. This is very important as majority of Africans live in the rural areas and are small scale farmers. A reform of the agricultural sector will provide a foundation for an export-oriented growth process. This should be accompanied by reform of land tenure systems which gives incentives to rural families to increase production and consequently increase in food supplies and incomes. Underpinned by public investments in rural infrastructure, better seedlings, irrigation systems, and technologies, the surpluses generated by small farms in rural-Africa could become the foundation for economic development. This achieved through the transfer of capital and labour to towns and cities from an increasingly diversified and productive agricultural sector. 
Experiences from China and elsewhere show that the role of agriculture for transformation is very important because of the role of agriculture in shared growth and the reduction of poverty and inequality. Furthermore, it is important that African governments, during the early stages of transformation, do not switch sectoral attention away from agriculture, as it will slow down transformation rather than stimulate it. This is because shifting attention away from small farmers during the process of agricultural modernization marginalizes a large group of the African population, contributing to social tensions. Moreover, it complicates long-term poverty reduction and improvements in income inequality, even after middle-income status is attained.

\section{Science and Technology}

Investments in science and technology are key for the agricultural transformation and ultimately industry. These investments are critical, because science, technology, and innovations contribute to raising productivity and consequently growth. The adoption to new technologies would have to begin with farmers. This was the case in China where the adoption of modern technology was key for agricultural transformation, as smallholder farmers became vanguards in the adoption of new technologies, raising agricultural productivity. It is important that in this framework, appropriate policies are introduced that will remove any urban- and industry-biased policies in trade, marketing, taxes, and other macroeconomics. It is therefore important that there is adequate public investment in rural infrastructure, including irrigation, and the provision of agricultural research and extension to a majority of farmers as well as increased research into African-specific improved crop varieties. Furthermore, investment in research and development in the agricultural sector is critical, as transformation is dependent upon investment in agriculture, and this investment will pay off, if farmers have the opportunity and incentive to transform the traditional agriculture practices.

\section{Infrastructure}

There can be no transformation, if there is no affordable efficient infrastructure. The development of well-functioning infrastructure is critical to Africa's social and economic development. Infrastructure in the form of electricity, ICTs (information, communications, and technologies), roads, rail, airports, seaports, and waterways powers economic growth and contributes to human development. Much of current infrastructure in Africa is inadequate or in poor condition. Estimates indicate that this situation is reducing production in industries by about $40 \%$ and makes doing business on the continent more costly. Africa does not lack plans to develop its infrastructure. What it lacks is the means to developing the infrastructure. The overarching goal of African governments is to mobilise support for scaling up infrastructure financing including recommending concrete measures to scale up and diversify sources of affordable infrastructure financing as well as explore new mechanisms for this purpose.

Addressing the infrastructure deficit in Africa would require massive investments for the operation and maintenance of existing infrastructure. It is estimated that Africa needs around US\$93 billion each year (about 15\% of the Africa's GDP), for the next 10 years, to bring its infrastructure to world class level. Two-thirds of this amount is for capital expenditure and the remaining one-third for operation and maintenance requirements. Investments are needed to: develop an additional 7,000 megawatts a year of new power generation capacity; enable regional power trade by laying 22,000 megawatts of cross-border transmission lines; complete the intraregional fibre-optic backbone network and continental submarine cable loop; interconnect capitals, ports, border crossings, and secondary cities with a good quality road network; provide all-season road 
access to Africa's high-value agricultural land; more than double Africa's irrigated area; provide clean and portable water and sanitation so that the continent will meet the MDGs; raise household electrification rates by $10 \%$ points; and provide global systems mobile voice signal and public access broadband to $100 \%$ of the population.

Despite the limitations, it is imperative that African governments find the resources they need to address the infrastructure deficit on the continent. The leadership of the continent may consider using revenues from natural resource extraction for the public financing of infrastructure. African governments may also consider raising funds for financing infrastructure through the establishment of regional infrastructure banks, sovereign wealth funds, and infrastructure-indexed bonds. It may also consider implementing long-term institutional and financial reforms to deepen access to capital markets as well as establishing an Africa Investment Guarantee Agency (AIGA) to mitigate country risk.

\section{Strengthening Manufacturing}

The manufacturing sector is a dynamic force in any economic transformation. While the share of developing countries' contribution to global manufacturing value added rose from $19.6 \%$ in 1995 to $33.6 \%$ in 2009, mainly due to China, Africa's share remained marginally at only $1.2 \%$, with half attributed to South Africa. Furthermore, African economic growth is currently driven largely by exports of oil, minerals, and agricultural commodities with little or no processing involved. To accelerate sustainable and inclusive growth and development, Africa needs to exploit new approaches including strengthening its manufacturing sector, particularly the exploitation of agribusiness. This will involve adding value to agricultural products and employment along the entire value chain in agribusiness and value chain in agriculture, industry, and services.

Compared to other manufacturing, Africa has a great potential in agribusiness. This is because most of African economies are agrarian based. Agribusiness provides inputs to farmers and connects them to consumers through the financing, handling, processing, storage, transportation, marketing, and distribution of agro-industry products. The potential for uplifting many Africans from poverty is manifold, as it touches all sectors of the economy. To understand, one has to decompose the sector into four main groups: (i) agricultural input industry (seedlings, fertilizers, insecticides and pesticides; irrigation system, agricultural machinery, and equipment and tools); (ii) agro-industry (food and beverages; leather and leather products; textiles, footwear and garment; wood and wood products; rubber products; and construction industry products based agricultural materials); (iii) equipment industry for agriculture (plant and machinery for processing agricultural raw materials, including storage facilities, cooling technology, and spare parts); and (iv) services to support agriculture (financing, marketing, packaging, distribution systems, transport, ICTs, and research and development centres). Clearly, developing each of these groups has the potential of creating massive employment and raises family income levels as well as accelerates growth through multiplier effects on other parts of the economy.

Given that manufacturing and services are main drivers of transformation, it is important that the private sector is deeply involved in the development and is supported by government policies and public investments. Improving the physical and institutional environment is crucial for creating the right incentives for the private sector to do business and generate the appropriate competition. Moreover, manufacturing is often more labour-intensive and usually creates strong linkages with the rest of the economy, particularly with agriculture, by using agricultural materials as inputs. Moreover, manufacturing often develops in rural areas as rural 
non-farm activities and the creation of rural manufacturing has often played an important role in poverty reduction and rural transformation.

\section{Strengthening the Management of Macroeconomic Stability}

A stable macroeconomic environment is a necessary ingredient for enhancing the transformation process. African governments should therefore strive to maintain macroeconomic stability. African governments should therefore aim at sustained economic growth and improved living standards of its citizens by establishing a stable economic environment for entrepreneurs. Indeed, in such stable economic environment, comprising careful inflation management and public finance stability, entrepreneurs would expect to face a steady rise in demand and stable production costs. Consequently, they would be able to plan their production and marketing and investment strategies, which would translate in the development of the production sectors of local goods.

Discretionary fiscal policies should be used appropriately by African governments to sustain aggregate demand depending on the availability of domestic and external financing. In embarking on expansionary fiscal policies, African countries should carefully assess the impact of the policies on debt sustainability. It is also important that African monetary authorities remain vigilant and embark on policies that will prevent excessive inflationary pressures.

African monetary authorities may also use exchange rate changes to achieve competitiveness and growth. In this case, real exchange rates adjustments must be allowed to respond to terms of trade shocks. It is also extremely important that there is coordination between monetary and fiscal authorities so as to avoid overvaluation of the exchange rates, which could potentially impair longer-term economic growth and derail the transformation efforts. Capital inflows and outflows should not be impeded and must generally be allowed to respond to exchange rate movement. In this regard, government should generally refrain from using its foreign currency reserves to prop-up an overvalued foreign exchange. In the event that the currency is under severe speculative attack, governments may intervene in the market to ward off the attack. However, if a current account is persistent and can no longer be supported with capital inflows, then the currency should be allowed to depreciate to help smooth the adjustment.

Strengthening regional integration in Africa remains the best strategy for Africa to lift itself up from poverty. This is because by pooling its 54 fragmented economies into one continental economy, African would become a vibrant economy capable of competing in the global market place and by so doing increase income and reduce poverty. Hence, the above framework must be implemented in the context of deeper regional integration. This is because by pooling its 54 fragmented economies into one, Africa will be able to compete effectively in the global arena and by so doing increase income levels of its citizenry and therefore alleviate poverty.

In deepening continental integration, Africa Union may consider speeding up the establishment of an African common market so as to increase internal trade within the continent which in turn will spur economic growth and poverty alleviation. Africa may also consider deepening the integration of financial and monetary markets. The merging of financial markets into a common financial market would be a powerful source and driver of capital flows to Africa. A single financial market would contribute to the mobilization of the financial resources needed to finance the continent's integration agenda including infrastructure projects. Furthermore, Africa should remain steadfast on its path of democratic reforms, elections, as well as political and economic 
governance, as they are the necessary ingredients needed to create the enabling environment for the transformation.

\section{Conclusions}

Africa needs to develop its own transformation agenda. This paper after briefly reviewing the literature on economic transformation has proposed a framework that Africa could consider to form the pillars of its transformation agenda. The process needs to be owned by Africans and not be driven by donors. The sources of transformation summarized in the paper are the key for the successful transformation of the continent. It is therefore imperative that meaningful indicators for measuring successful transformation should be developed by Africans. It must all be understood that transformation leads to rapid economic growth and consequently raises income levels of the poorest segment of society. Given the level and persistence of poverty and rising income inequality, the returns of the socio-economic transformation must be used to address the socio-economic inequalities of society.

Going forward, it is within the grasp of Africa to transform itself into a middle-income continent within a generation. This will require a development agenda whose implementation is inclusive and it is aimed at uplifting majority of the citizenry from poverty as well as growing the middle class. Africa may consider using deeper forms of regional integration to boost intra-African trade as well as find innovative financing mechanisms support regional infrastructure. It is equally important that Africa begins its transformation through agricultural modernisation and using it as a launch pad to create a dynamic and sustainable economic growth at large. Furthermore, Africa should enhance the use of science, technology, and innovations to pioneer its growth agenda, as well as use ICTs to leapfrog knowledge acquisition for its development.

In concluding, it is very important for all Africans to note that Africa has to be developed by Africans. "Hand outs" glorified as aid/grants alone will not change the lives of the many poor citizens of the continent. Ultimately, Africans are totally responsible for the development of the continent and therefore should shoulder the burden of financing its development, no matter how long it takes and how painful it may be.

\section{References}

Breisinger, C., \& Diao, X. (2008). Economic transformation in theory and practice: What are the messages for Africa? Retrieved from http://www.ifpri.org/sites/default/files/publications/ifpridp00797.pdf

Chenery, H. B., \& Taylor, L. (1968). Development patterns among countries and over time. Review of Economics and Statistics, 50, 391-416.

Heath, J. R. (1992). Evaluating the impact of Mexico's land reform on agricultural productivity. World Development, 20(5), 695-711.

Krueger, M. (1988). Policy lessons from development experience since the Second World War. In H. Chenery and T. Srinivasan, (Eds.), Handbook of development economics. New York: Elsevier.

Kuznets, S. (1955). Economic growth and income inequality. American Economic Review, 45, 1-28.

Kuznets, S. (1973). Modern economic growth: Findings and reflections. American Economic Review, 63(3), $247-258$.

Rodrick, D. (2007). One economics many recipes: Globalization, institutions, and economic growth. Princeton: Princeton University Press.

Rodrik, D. (2004). Rethinking growth strategies (WIDER Annual Lecture 8, UNU World Institute for Development Economic Research (UNU-WIDER)). Retrieved from http://www.wider.unu.edu/publications/annual-lectures/en_GB/AL8/_files/

Schumpeter, J. (1947). The creative responses in economic history. The Journal of Economic History, 7(2), 149-159.

Syrquin, M. (1988). Patterns of structural change. In H. Chenery and T. Srinivasan (Eds.), Handbook of development economics. New York: Elsevier. 